\title{
The Galician Mussel Industry: Innovation and changes in the last forty years
}

\section{Uxío Labarta* and $M^{\mathrm{a}}$ José Fernández-Reiriz}

Consejo Superior de Investigaciones Científicas. IIM - CSIC. Instituto Investigaciones Marinas. Eduardo Cabello, 6. 36208 Vigo. Spain

\section{*labarta@iim.csic.es}

\begin{abstract}
The mussels industry with a production that accounts for more than twenty five percent of the fresh product landings from the sea, and the full-time employment of more than 8,000 people, is by far the largest productive activity of the Galician sea.

In the 1980s was noticed an increase in productivity related to processes of innovation in the industry of mussel. Together with it, the first organizational forms of the Galician-based production sector was constituted, with a spatial and administrative reordering for mussel rafts and crops. A new reality of the sector was maintained in both the marketing guidelines and the fact of initiating a vertical integration between the mussel industry and the commercialization. Everything was accompanied by changes in markets and strong tensions: derived from red tides that limit the operating cycle and even its profitability and also from the conflicts between the producing and transforming organizations, added to the competition in the markets of other countries, mainly Chile.

The reality of mussel culture and markets leads to a reformulation in the industry, with strategies for territorial diversification of suppliers, new technological improvements in production and even organizational, economic, and bioecological innovations.
\end{abstract}

\section{Introduction}

Bivalve molluscs, shellfish products and marine cultures achieved a certain level of economic potential in Galicia in the 1960s during the first stage of Spain's economic development at that time, under the so-called Stabilization Plan and Development Plans of 1959-1974. This was the result of the creation of a “calcium carbonate” gastronomic culture (Labarta, 1997), promoted by Galician seafood marketers, who took the myth surrounding oysters and their symbolism to render other bivalves, with the exception of mussels, as symbols of celebration and social status, all the way to our times and generalized with the arrival of shrimp to our markets.

The economic effects of this cultural change on shellfishing and the establishment of mussel, oyster and other bivalve farms they are due by the increase, in the first sale, of the price of such products between the years 1962 and 1972 . While the price of oysters grew by $666 \%$, that of cockles by $500 \%$, and that of clams by $356 \%$, mussel prices only increased 32\% (SOMEGA $\left.{ }^{1}, 1975\right)$. In addition,

1 Mussel Farmers Society of Galicia 
according to the study sponsored by SODIGA ${ }^{2}$, to the years 1970-1972, mussel farmers, called bateeiros (raft men) in Galician language, received only $17 \%$ of the value paid for mussels by the consumer, in contrast to the proportion earned by fresh fish ship owners, which was $48 \%$ of the price paid by the final consumer. On the other hand, mussel production in that same period increased by $290 \%$ (from 48,000 to 138,000 metric tonnes), and the number of rafts by $90 \%$.

At present, although the number of rafts remains at around 3,300, similar to that of 1972, the production in the last thirty years has been around 250,000 tonnes per annum, twice as much as in 1972, of which some 225,000 tonnes are marketed (Labarta, 2004).

\section{The evolution of mussel farming}

In order to understand the origins of mussel farming, we must first approach the history of oyster farming, which in Galicia dates back far in time, starting to decline in the $18^{\text {th }}$ century. Oyster farming had long focused on the recovery of its natural oyster beds, in harvesting the seed, and marketing. In parallel, mussel farming activities began in the 1930s at an industrial scale, as recorded by Fernández González (2005).

In collaboration with the biologist Manuel Sánchez of the Spanish Institute of Oceanography (IEO), the company Viveros del Rial SL had started its activity in oyster culture and later assessed the opportunity for the future in mussel farming. Initially with the "bouchots" French method, later on opting for growing the mussels suspended on ropes hanging from fixed or floating platforms. The latter system was originally developed in Italy, and according to Odón de Buen and Rodríguez Santamaría, it was later installed in Tarragona, then in Barcelona and Valencia and, subsequently, elsewhere along the Mediterranean. Eventually, this type of farming was limited to the area of the Ebro Delta due to a shortage of seeds (mussels around $20 \mathrm{~mm}$ ) and competition for space in protected port areas. The importance of mussel farming in the Mediterranean had a demonstration effect, though it enabled to establish a stable demand in many cities along the Mediterranean coast.

In the year 1927, the Ozores-Saavedra family took an interest in shellfish farming. After several failed attempts to grow oysters, the company Viveros del Rial SL, established in 1944 with an initial capital of 2.5 million pesetas, saw the need to engage in mussel farming using the suspension system previously tested in the Mediterranean area. In 1946, the company owned by the Ozores Saavedra (Viveros del Rial SL) installed the first experimental raft and before the end of the year they had already anchored ten such rafts destined for production near the port of Vilagarcía de Arousa, and named them "M1" to "M10". During the first ten years, many canneries were present among the 250 awardees of 1,110 concessions for mussel farming. The cannery industries comprised one-tenth of the applicants and yet they were given a quarter of the concessions. According to this fact, the development of mussel farming is associated to such kind of initiatives in the canning industry, although the canneries that took part in the concession of mussel farms only accounted for $15 \%$ of the total existing canneries in Galicia, most of them from the Ría de Arousa (according to Fernández González, 2005). Very few pioneers had their residence away from the coast or outside of Galicia, and they all had stakes in the Mediterranean mussel markets.

2 Society for the Industrial Development of Galicia 


\section{Reasons for farming}

In the beginning, there were two well-differentiated mussel markets: the demand for fresh produce, concentrated along the Mediterranean coast which had grown accustomed to consuming mussels since the beginning of the century, especially in Barcelona; and the demand of the canning industry in Galicia.

These initial markets expanded as from the 1960s with the overall increase in purchasing power, the demand associated to tourism, and the introduction of mussels into other, non-Mediterranean urban markets, in addition to a rising demand for canned products.

During the initial stages of mussel farming, in the post war Spanish and World war years, many entrepreneurs saw their activity limited due to the lack of essential supplies, either because internal production was scarce and / or deficient, or because it was difficult or impossible to import them. However, the emerging mussel farming industry had fewer constraints. The need for wood, rope, boats or seed was easily satisfied locally; and the labour-intensive activities of mussel farming took advantage of the availability of labour force given that other industries were less active after the war.

The Administration fostered access to the maritime public domain regarding the installation of nurseries and the collection of seed along the rocky coast. The installation of nurseries was governed by a Royal Order of 1930, which was modified in 1953 (Order of 16-XII, BOE No. 356) establishing the minimum requirements for applicants.

In the beginning, there were difficulties with the cultivation and marketing techniques. Farming activities had developed on a totally empirical basis and the trial-and-error method, both at the technological level and regarding the knowledge of mussel biology and ecology, the natural habitat, as well as mussel behaviour as a farmed product. Once the technical difficulties were overcome successfully, the commercial problem was raised. Although the Mediterranean demand was on the rise, it was a limited, relatively distant market. Mussel's farmers were small producers who sold a perishable product and lacked the ability to control prices and marketing and to open up to new markets.

The production-marketing binomial has conditioned mussel farming right since the beginning. Marketing has been the greatest weakness at the initial stages because supply grew faster than demand. In this context, Valentin Paz Andrade wrote in 1955: "if what seemed obvious would have been forecast, the industry would have joined forces and become organized in order to explore new markets and increase consumption”.

At that moment, a third element appeared to accompany the evolution of the industry of mussel farming: the production was divided into small holdings, with barely any capacity of association of such small producer/family farms, a common problem which lasted well into the mid-1970s.

However, all these difficulties of market versus production, and even of the marketing itself in which demand behaved as an oligopoly and limited the prices paid to producers despite rising production costs did not curtail the development of mussel farming.

\section{The legal and regulatory framework}


It was only in the 1960s, during the economic expansion and the political changes brought about by the Spanish Development Plans when the legal framework governing the breeding sites for bivalve molluscs was reviewed. These years saw profound changes in the world of the sea, in economic, technological and market terms. Fishing underwent a major industrial transformation with on-board freezing, and this, in turn, led to government action and legal reforms.

New standards were developed for shellfish farming related to licenses or concessions and cultivation areas, first by means of the Decree 2559 of November 1961, and later on, by an Order of the Ministry of Commerce in 1963 providing for the establishment of 4,750 points to anchor the rafts. Such an offer caused many individuals to install rafts or to trade with the concessions.

Another decree was issued in 1962 governing concerning seafood purification plants and the regulation for "Recognition of the Quality and Health of Molluscs". This brought important changes in the mussel farming industry, especially in the marketing of the produce, given that many of those who developed the first mollusc treatment plants were at the same time the concessionaires of shellfish farm or shellfish traders. The importance of the purification requirement for the fresh product changed the stakes for the marketers and reinforced their oligopoly.

\section{The growth of farming}

Between 1946 and 1960, more than 2,000 licenses were granted for rafts, although only about 1,100 were actually installed, which in the first year produced about 300 tonnes, according to the data by Duran et al. 1990. In 1960, production amounted to 61,000 tons (Andreu, 1976), growing close to 8\% per year. Between 1960 and the enactment of the law on seafood in 1969, 2,800 rafts were installed that produced some 160,000 tonnes. The figures 1 and 2 show the growth of production according to the estimates made by Andreu (1976) and Porta and Pardellas (1987). Historically, it was Andreu who estimated the first mussel productions between 1956 and 1975. According to these estimates, the output grew from 22,500 tonnes produced by 410 rafts in 1956 to 61,550 tonnes produced by 1,099 rafts in 1960. In 1966, 2,050 rafts produced 114,000 tonnes. In 1975 , there were 3,134 rafts which were producing 175,500 tonnes.

On the other hand, according to Porta and Pardellas (1987), the purification companies rapidly developed in the period from 1964 to 1975. Some thirty-five were built, out of which about 25 were installed in Galicia and another 10 elsewhere in Spain. According to the same authors, it is estimated that the average annual amount purified is around 50,000 tonnes, accounting for $30 \%$ to $40 \%$ of the mussels harvested.

During this stage, the first biological and ecological studies were conducted on mussel farming and its relationship to the ecosystem of the Rías. This research was carried out by scientists of the CSIC ${ }^{3}$ : initially by Andreu, Fraga, and Margalef, and subsequently by Figueras Monfort.

\section{The maturity of mussel farming. 1976}

The year 1976 marks the beginning of the Political Reform in Spain, and the mussel farming industry begins its maturity phase. In this year, the number of

3 Spanish National Research Council 
installed rafts was equal to the number today, totalling around 3,300. It was also in that year when it was established that during a period of 3 years, extendable, no further applications for licenses to set up floating mussel farms would be accepted or processed. The measure was justified by the "evident imbalance of the mussel market due to decreasing demand [and] diminished quality that was detected due to an excess of production (...)" and the desire to foster "the vertical cultivation of other, more profitable and more demanded species” (BOE $n^{\circ} 113$, p.18131).

Since then, the limitation of mussel production began in Galicia which continues to this day as the main strategy for its economic management.

In addition, the first cases of "red tides" were recorded which had an impact on the market, to become a constant feature in the following forty years, conditioning the development of mussel farming and its profitability. The first cases of poisoning appeared in Switzerland in 1976, then the bombshell exploded in France. The red tide, also known as "algal bloom", has become one of the determining elements of farming and marketing of mussels and other molluscs in Galicia since the mid-1970s. The first toxic episode was described in 1978 and the most extensive one in 1981 (Gestal, 2003). A red-tide monitoring program has been developed since 1977, which has increased the knowledge and control of the toxins in bivalve molluscs with a special emphasis on mussels (Campos et al. 1982).

It was during those years when the first attempt was made to create an organization to unite the interests of small producers in order to market mussels, SOMEGA.

Although SOMEGA was short-lived, the limitation of the number of rafts continues to this day, as do red tides, and these two factors have important effects on the mussel industry.

In 1976, there were a total of 5,500 anchorage points distributed in 78 lots, known as "polygons". However, since some many of them are in shallow waters or very exposed areas, about 2,000 are unused. Subsequently, with the aim to improve production and for the sake of administrative clarification, a new framework was established with 84 polygons distributed in 19 districts.

The distribution of rafts is shown in figure 3 . They are grouped in 63 polygons, although three of them are not occupied; $69 \%$ of the rafts are concentrated in the Ría de Arousa, and this is the area where the property is more disaggregated, with an average of 1.15 rafts per owner, slightly below the average for Galicia (1.35), and where there are only 9 owners with more than 4 rafts (ranging from 5 to 14). Only the Rías with fewer rafts (Ares-Sada, Muros-Noia and Pontevedra) have a greater concentration of raft ownership (14.7, 4.1 and 2.4 respectively), (fig. 4).

From a historical point of view, the concentration of ownership has varied considerably. In the study by SODIGA (1975), the number of owners was estimated between 980 and 1,150. The existence of large companies associated with the canning industry which were owners of a large number of rafts was also recorded, although in decline. Towards the end of the 1960s, these companies started to sell their rafts, mainly due to increased operating costs, particularly wages, in a context of stagnated prices. From the year 1974 to the present, the average ownership has dropped from approximately 3 to a mere 1.2 rafts per owner, evidencing not only the problems arising from the hereditary transmission but also of individualized access to the property. Nevertheless, the trend -as far as possible- has been to concentrate or combine production units in order to optimize the cost-yield ratio. 


\section{Mussels production per raft}

Nowadays, the average annual production per raft has been estimated at 75 tonnes, ranging between 60 and 84 tonnes depending on the area and type of product. Data from the Consello do Mexillón de Galicia ${ }^{4}$ estimate the following yields: 50 tonnes per raft/year in 1995, 67.4 in 1999, and a maximum of 70 tonnes in 1997.

Comparing the production data with previous estimates made on the average productivity per raft, an average production of about 75 tonnes per raft/year has been estimated for 1997, with a range between 60 and 84 tonnes depending on the area. Andreu (1982) had estimated this production at 58 to 60 tonnes per raft, and Pérez Camacho and Román (1981) at around 68 tonnes. The data provided by Durán et al. (1991) establish the following time sequence of production per raft: 30 tonnes in 1946; 56 tonnes in 1961; 60 tonnes in 1976 and 75 tonnes in 1991.

It is necessary to point out that all the previous data refer to the production of mussels on rafts, and not to the marketed product. Pérez Camacho et al. (1991), Mariño et al. (1982) estimated the marketable production (mussels larger than 70 $\mathrm{mm})$ at 47 tonnes per raft/year. No differences were observed between the two surveys (1977 and 1984) regarding the average yield per raft.

The statistics were calculated by approximation, and so there are historical series from 30 years ago with productions higher than those officially recorded in the 1980s and 1990s. This would not matter if it were not for the fact that in those thirty years not only the farming technology suffered substantial improvements but because, as Durán et al. (1990) point out, the average surface area of the rafts was $300 \mathrm{~m}^{2}$, compared to $500 \mathrm{~m}^{2} 30$ years later.

Porta and Pardellas (1987) estimated that production in the 1980s ranged between 210,000 and 250,000 tonnes of mussel per year, with the number of rafts already stabilized around 3,300.

This increase in productivity which may be observed between 1976 and the beginning of the 1980s may be related to the mechanization processes in the mussel industry. In addition to the use of cranes and pulleys, larger vessels, and the introduction of baskets, at that time two innovations were developed that entailed a great advance to improve production: on the one hand, the incorporation of the mussel retubing machine A-1, developed by Jacobo Aguín, and the introduction of the tubular mesh, later improved with the Cotton Plus (JJ Chiccolino). Subsequently, the use of conveyor belts, hoppers, husker brushes, and deburring machines contributed decisively to the improvement of production and productivity, together with enhanced materials and design of the fishing boats, already conceived as working platforms enabling to start processing mussels on board. Such innovations and improvements have received support from the European Fisheries Fund since 1986.

\section{Research in the Rías and mussel farming}

The collaboration between Isidro Parga Pondal and Margaretha BrongersmaSanders generated a broad scientific collaboration with the Netherlands. Attracted to the Ría de Arousa by the importance and singularity of mussel farming in rafts, they approached studies on the geomorphology of the Galician coastline (H. Nonn 
and AJ Pannekoek), on the biocenosis of the molluscs in the Ría (GC Cadée), and the oceanography of the rías in the seminal work by L. Otto in 1975, "Oceanography of the Ría de Arousa”.

In the mid-1970s, under the Spanish-North American Friendship, Defense and Cooperation Agreement, an ambitious project was started that focused on the multidisciplinary study of the Rías directed by K. Tenore from the Skidaway Institute of Oceanography, USA, and J. Corral from the Spanish Institute of Oceanography. The results of these studies (Tenore and González, 1975) and Tenore et al. 1982) were the first attempts to achieve an ecosystem approach to marine aquaculture and were made in the Rías of Arousa and Muros; and a firstgeneration model to optimize the exploitation of mussel rafts in the Ría de Arousa was published by Wiegert and Penas-Lado (1982). This earlier work with a mussel growth simulation model predicted the carrying capacity for optimum production under average coastal upwelling conditions, with maximum yields of 105,000 tons $\mathrm{y}^{-1}$. When upwelling is weak, the high mussel population density results in low biomass of individual mussels and, thus, poor marketability. Blanton et al. (1987) also showed the first quantitative relationship between upwelling intensity and mussel condition index. In this same program, PérezCamacho and Román and their collaborators developed a broad, seminal study on mussel farming and its interaction with the ecosystem in the Ría de Arousa, whose results were published between 1979 and 1982 in the Journal of the Spanish Institute of Oceanography. In addition, there are other works by Figueras Monfort (1976) on farming aspects and Aguirre (1979) on mussel biology.

\section{Innovation and changes in the Galician mussel industry}

Our approach to innovation and technological change in the Galician mussel industry is indebted to the concepts developed by Schumpeter (1942), which holds that the innovation encompasses a multiplicity of phenomena synthesized in: product and process innovation, opening a new market, the development of new sources of materials for production; and the development of new organizational forms in the industry, to which reference is made in the market structures. Schumpeter emphasizes as innovation not only the destructive creation where new inventions make obsolete old products. But also, and very important, innovations based on the "creation" of new combinations of existing technologies. In summary, the company is the central agent that takes the technological progress in applications and introduces them in the market.

\section{1 .Mussel farmer organizations}

The fragmented property of the mussel industry historically generated a dependence on the marketing sector, whereby the economic relations not only prevented the development and capitalization of the sector but also obliged producers to bear with low profitability and to assume the economic risks generated by the tight margins and erroneous strategies of the marketers.

According to Castelo and Pérez Dorca (1997), It was in the decade of the 70s and 80s when the first associative structures of the sector appeared with the aim of acquiring negotiating capacity to establish and maintain prices, as well as to have 
a guarantee of collection (i.e. SOMEGA, AMC, AMEGROVE, FEPMEGA, OPEMAR, OPMEGA).

The organizational evolution of the mussel industry led to the development of new business strategies for the integration between production and marketing and, more recently, production, processing and marketing. In any case, it was a long process closely related to the evolution of the markets and also to the business maturity of the mussel farmers themselves.

The establishment of the Regulatory Council of Mussel from Galicia in 1995 has had a significant impact in this process, with the approval of the designation of "Galician Quality Product"; and from the year 2000 with the provisional approval of the EU Protected Designation of Origin “Mussel from Galicia”. Its importance lies in the protection and regulation of a cultural added value, as is the origin in the Rías of Galicia, to be exclusively used for mussels from this origin, similarly to the case of the trademark "Green Mussel” for New Zealand mussels.

In recent years, there have been formulas for the integration of the mussel production industry with the marketing of the fresh produce (Labarta, 2000). Thus, together with the first mussel associations that became equipped with purification plants and established their own marketing networks for the fresh produce, there are a number of companies of different sizes that have integrated production and marketing fresh, and even in some cases by integrating the processing (freezing, pasteurization, airtight packaging atmospheres...).

Regardless of the fact that all of the above may point towards a future trend, the viability of vertical integration (production-processing-marketing) may not be analysed for the overall mussel sector, since there are very different stakes within it. Nevertheless, this does not preclude the appropriateness of progressing with such integration, either by grouping producers together, or by means of stable supply and marketing agreements with the processing industry; especially if we take into account the advantages of semi-industrial or family farming industries against a fully industrialized system considering the seasonality and natural phenomena such as the red tides that render the viability of a purely industrial system very precarious.

In the mid-1990s, the organizational situation of the sector gradually became differentiated. This differentiation is associated with market and production strategies that are also distinctive.

The conflicts between the mussel organizations during the summer of 2008 were the culmination of the tension between the different marketing organizations and the integrated grass-roots associations, with respect to sales for both the processing industry and fresh produce. As a consequence of such events and strategies, there was a commercial war whose impact has not yet been estimated from an organizational, commercial and even legal point of view, such as the case of ANFACO's ${ }^{5}$ claim filed at the National Competition Authority. As a result of this strategy, we have also witnessed the creation of a new producers' organization (PLADIMEGA, a Distribution Platform for Galician mussels), which replaced the dissolved OPMAR (Galician Mussel Producers Organization) created in 1986. This new producer organization has already been recognized by the European Union, obliging its members to stay at least two years within the organization.

In 2014, the estimates obtained from the register of aquaculture establishments in Galicia draw the following associative profile: there are approximately 45 primary

5 National Association of Sea and Fish Canned Food Producers 
producer associations, which in turn may be integrated into association organizations. Out of these, five have between 150 and 300 rafts; there are 13 organizations in each of the categories of between 50 and 100 and between 25 and 50 rafts; another 10 associations with 10 to 25 rafts; and there are also some associations with less than five rafts.

In addition to OPMEGA and the Federación Norte, half a dozen producer associations from the Rías of Arousa and Vigo have recently formed the Federation of Associations of Mussel Farmers (FEMEX), which represents some 400 rafts.

At present, the evolution of the associative system in relation to sales organizations is unpredictable, and it seems that most of the producers who market fresh will hold agreements with the large retail chains, while those who sell mainly to the processing industry will remain in a broader organizational context.

Such organizations are the core on which to set the foundations and achieve the expansion of the mussel market, by promoting -in the light of an increasingly concentrated demand- adequate profitability, market stability and a supply of products that meets the demand of both consumers and the processing industry. In this context, the need arises for such organizations to adjust their actions to business management models, and to develop new industries capable of responding to the new market challenges. Because with or without European funds and subsidies it will be the market, and any strategies developed before it, that will mark the future of mussels from Galicia. This has been well understood by the mussel farmers themselves as well as the need to innovate in the bioecological and bioeconomic areas.

\subsection{Market and production evolution}

Following the wake of the Decree of 1976 (Boletin Oficial del Estado $n^{\circ} 113$ ) which limited mussel farming facilities on the basis of overproduction, some market studies in the 1990s helped to strengthen this perception. And so, Mac Allister et al. (1999), Escuela de Negocios Caixanova (2000), and Labarta (2000) addressed different aspects of the mussel markets. The effects of the Mc Allister Report, commissioned by the European Union, were of particular importance as it diagnosed a stagnation or decline for the mussel market in Europe, compared to the rest of the studies that predicted an expanding market.

Labarta (2004) argued that consumption would increase in the traditional seafood markets (Spain, France, Benelux and Italy), whereas the expectations for increased production would occur in non-traditional geographical areas unrelated to mussel farming. This fact would lead to an increase in imports in the larger markets, which coincide with European producer countries. The diagnosis by Labarta and Corbacho (2002) established that, in the case of mussels, this increase would occur in the markets for processed or added value products, in line with the new canning and processing technologies; and not in fresh markets, since the latter have the added problems of the cost of transporting the shells and higher health risks. In short, adapting mussel marketing to the new market demand, far from marketing them as if they were "chickens with feathers", which was a common practice until the 1990s (Labarta 2000).

Mussel producer organizations have been wrong in not designing appropriate market strategies. While in Galicia the strategy was to limit production in order to 
maintain profitability levels, an adequate perception of the trends in international markets, more also of Spain, led to increased pressure by the major retailers on the food industry (canned, frozen and processed foods) as was analysed by Fernández and Giráldez (2013). This, in turn, led to the positioning of other producer countries, which at first was limited to importing New Zealand mussels. Subsequently, and as a consequence of the internationalization of mussel farming on behalf of the Galician industry -as had happened to the fishing and frozen fish and major canning industries-, investments were made in farming companies in Chile but also in integrated industries, which allowed the Chilean mussel industry to become the Galicia's major competitor. Thence, although at the beginning of the 21st century the imports of mussels in Spain were not very high due to its status as the main European producer, they were indicative "either of market segments unattended by the Spanish production, or according to Labarta and Corbacho (2002) due to a greater competitive capacity to the characteristics and type of product” (large, medium and small mussels). Between 2000 and 2011 the total imports multiplied threefold and especially those originating from Chile (Fig. 5).

The Galician mussel sector, a traditional supplier to the canning industry, was faced with an external competition that marginalized it from the first stage of the global production chain. A challenge that provoked a deep crisis in the mussel industry and was forced to reorient its strategy to direct its offer to fresh sales, and to start a process of redefining the farming strategies. The close alliance between the Chilean mussel farming sector and the Spanish processing industry caused the Galician mussel to lose quota in the markets for processed products. By the end of the 1990s, the processing industry absorbed more than $60 \%$ of the mussel production, though, in subsequent years, the supply tended to concentrate on fresh sales, a process that took on place since 2007.

The data indicate that fresh markets in Europe are the exclusive competence of the relationship between producers and markets, without interference from third countries. The situation of the mussel market for industrial processing has been affected, not so much because of imported frozen mussels, but because of the direct imports of canned mussels, which in the last few years accounted for the equivalent of one-quarter of Spain's production; as well as due to the weight reached in the markets by the new preparations and non-airtight preserves.

Between 2007 and 2015, the marketed production of Galician mussels increased by $26 \%$ (see figure 6 ), with major fluctuations due mainly to the incidence of red tides and, in 2008, to one of the most serious conflicts between mussel producer organizations.

The innovation in production and markets is shown in Figure 7, which shows that by product type there is a decrease from $22 \%$ to $9.6 \%$ of the production of large mussels for the fresh market. A growth of $29 \%$ of the mussel medium, and an increase of 8 points of the small mussels that comes to represent $61.5 \%$ of the production for the fresh market. Innovations with wide effects on the mussels culture cycles and profitability of the mussel industry.

Nevertheless, the stability of prices and a total turnover between 74 million euros in 2013 and 112 million euros in 2015 are surprising, in correspondence with the marketed production, of which the lowest value in the series corresponds to the year 2013, with just 183,000 tonnes.

Conflicts between the mussel organizations, very serious between 2008 and 2010, and with the processing industry contributed to this oscillation of production. 
Changes related to the destination of the production and the type of products must also be taken into account. Thus, in the series analysed (see fig. 6), the destination of production, historically higher for industrial processing (in a ratio of 60/40), reached a turning point in 2007 when 50\% was sold fresh. In 2014, the production for fresh sales accounted for 65\% of the total, and in 2015 and 2016 it went back to the $60 / 40$ ratio. In terms of revenue, fresh mussels represented $55 \%$ of the overall turnover in 2007 and 62\% in 2015. Mussels for industrial processing were $45 \%$ of the turnover in 2007, and only $28 \%$ in 2015.

The fresh mussel markets, in which the producer organizations themselves own marketing facilities, together with the important volume exported especially to France and Italy have transformed the marketing channels in Spain. This is a consequence, from our perspective, of the increasing incidence of the major retailer chains, mainly Mercadona -who may have marketed more than 25,000 tonnes of fresh mussels from the Galician Rías- as well as others, such as Carrefour, Eroski and Gadis whose supplier strategy is one of agreements with processing companies, all of which enabled to consolidate the fresh market in Spain, as well the consolidation of around 40,000 tonnes of fresh mussels exported to Europe annually.

The strategies carried out by the major retailers of boosting the demand for fresh mussels are not limited to this product but also have a strong impact also on the frozen or canned mussels. In the same time period, a number of companies, either mussel producers or integrated industries, started to develop a whole range of products for families or restaurants ( $\mathrm{V}$ range products) based on the new conservation technologies available, either for fresh mussels or precooked dishes. The data published by FAO, Monfort (2014), establish that Spain, France and Italy, with $35 \%$ of the European population, representing $78 \%$ of mussel consumption, while if we add another five countries (Germany, Denmark, Belgium, UK and Greece), which equals reaching $65 \%$ of the population of the $\mathrm{EU}$, all together they account for $96 \%$ of the total consumption of mussels in Europe.

The reality of European markets (EUMOFA 2015) establishes that the European mussel market is of around 600,000 tonnes in weight- equivalent of live animals, of which 500,000 tonnes are of national origin, and another 100,000 tonnes of international origin (the net balance of imports and exports).

In Europe, Spain produced 46\% in volume in the year 2015, although it was France that increased its production by 17,500 tons, a $30 \%$ growth in volume. (EUMOFA 2017). The differences in the average price between the French mussel (1.8 Euros kg) and the Galician mussel (0.51 Euros kg), could be due to the fact that French is directed only to the fresh mussel market, and the Galician mussel serves product markets fresh and processed.

The popularity of mussels varies from one country to another and the annual per capita consumption ranges between less than $200 \mathrm{~g}$ and almost $4 \mathrm{~kg}$, depending on the country, with an average of $1.33 \mathrm{~kg}$ per person and year for the whole of the EU 27.

\subsection{The Galician mussel culture: Biological and ecological innovations}

The production strategies implemented in order to meet the demand led to changes in farming strategies, and even to an evaluation of the carrying capacity of the ecosystem. 
Both the adequacy of production to the demands of the markets and the bioecological optimization of mussel farming itself are sustained in a greater turnover due to shorter cultivation periods, lower labour costs, and also higher productivity; albeit with higher operating costs and, above all, the increased need for seeds to start the growth process. Mussel farming is extensive, both in the capture and in the collection of mussels, and requires no animal feed; the increasing need for mussel seed needs to be optimized, both in the collection along the coast as well as when strung on ropes.

In this context, in 1987, research on mussel farming in Galicia was resumed by a consortium comprised of the Spanish Institute of Oceanography and the CSIC. In 1989, the $1^{\text {st }}$ International Mussel Congress was held which dealt with different aspects and advances of mussel farming. It was organized by the Seminario de Estudos Galegos with the sponsorship of the Regional Department of Fisheries and under the scientific presidency of Dr Brian Bayne, with a monograph published in the Aquaculture Journal in 1991. As a result of these studies, the importance was established for the origin of the seeds, of the farming area and of the abundance of phytoplankton for mussels to grow (Pérez-Camacho et al. 1995, 2013 and 2014). Labarta (Ed) (2004) includes the eco-physiological (FernandezReiriz and Labarta, 2004) and bioeconomic research (Labarta, 2004) carried out on Galician mussels and their markets (Labarta and Corbacho, 2002).

This research has been continued with the studies carried out by the CSIC-IEO Mussel Lab in its collaboration with OPMAR, then with its successor OPMEGA, and later on with the newly created Regulatory Council of Mussel from Galicia, until 1997, further on in the seas of Lorbé by the CSIC-PROINSA Mussel Lab.

The complexity of the farming system has been studied intensively in order to optimize its different stages, to increase and adapt production to market demands; but also to its bioecology, by reducing costs and increasing production without changing the status quo established in 1976, and confirmed in 1986, of not increasing the number of rafts.

The average length of the cultivation process was around 18 months: For a part of such time, the ropes with mussel seed coexisted with ropes destined for fattening. This means that the rafts, which have a legally limited maximum number of ropes (500), could only occupy between 66\% and 75\% for fattening (Pérez-Camacho and Labarta, 2004), thus limiting significantly their production capacity.

On the other hand, over the years it has been necessary to modify the classification of the products to be marketed, increasing their number and reducing the minimum size. Thus, at the end of the 1990s, there were only 3 commercial categories depending on the size of the mussel, and the minimum commercial size was $70 \mathrm{~mm}$. Eventually, there were 5 commercial categories and the minimum size was $50 \mathrm{~mm}$. These new commercial categories not only adapt better to market demand but are also more in line with the biological and ecological processes of farmed mussels (Pérez-Camacho et al. 2000). This has allowed in recent years to increases the production of mussels on all the rafts in Galicia, and especially the marketable production (Fig.7).

Moreover, there are the advantages derived from the increased use of mussel seed from collector ropes compared to the traditional, formerly prevalent seed collection from intertidal rocks (Pérez-Camacho et al. 1995, Babarro et al. 2000). This new situation made it necessary to develop new farming techniques more in line with the characteristics of the market and also in order to increase raft yields, reducing cultivation time and operating costs. The studies carried out by Pérez- 
Camacho and Labarta (in Labarta 2004) concluded that similar biomass productions could be obtained in less time with a new technique of cultivation without thinning, if compared to the traditional technique using thinning, although with smaller individual mussels. Moreover, this technique without the thinning, despite the high work density involved, limits losses due to mortality or detachment, which never exceed $10 \%$. The results obtained in the above mentioned work enable to validate the technique without thinning, both in terms of production as well as in economic yield, depending on the density of the seeds planted, for mussels of a commercial category of 45 to 70 pieces per kilogram, which is one of the categories most demanded by the European market.

In order to optimize and regularize production, in addition to the tasks pertaining to farming itself, it was necessary to know which natural elements have the greatest influence on production, such as the amount of phytoplankton and the speed of water currents, two factors that determine the amount of food available; and also to adjust the binomial of available food vs cultivation density for each one of the raft zones or polygons in the Rías (Pérez-Camacho et al. 2014).

These studies carried out over the past 30 years have enabled to introduce a Mussel Management Production system in the farming process that brought about significant improvements in the economic value per raft and year.

As a continuation of the projects developed in the Ría de Arousa, which has the largest number of rafts $(2,300)$, a new stage of research and innovation started in 2002 in the Ría de Ares-Betanzos in collaboration with the company PROINSA MUSSEL FARM within the framework of the CSIC-PROINSA Mussel Lab. This new stage of research was directed to the study of seed recruitment and the biological factors that regulate it (Peteiro et al, 2010, 2011, Fuentes-Santos and Labarta, 2015) by developing predictive models on the start and intensity of collection in relation to oceanographic and environmental variables (FuentesSantos et al. 2014, 2016) ; the effects of fish predation on mussel seed and its alternatives (Peteiro et al. 2000); as well as a detailed study of the effects of production density on the total yield of the rafts (Cubillo et al. 2012,2015) together with an assessment of costs and optimization in a bioeconomic model (Fuentes-Santos et al 2017).

During this stage, a predictive model was developed on the food, its quality and abundance (Aguiar, 2015), and the analysis of growth models (Álvarez-Salgado et al. 2017, Fuentes-Santos et al. 2017). Models were also developed of the water circulation in the Ría and through the rafts (Cranford et al. 2014, Piedracoba et al. 2014, Duarte et al. 2014, Aguiar et al. 2017) , which models allow to establish residence times and available food based on meteorological variables that determine such parameters and the potential clearance area of the raft. In the last decade, the increasing recurrence of harmful microalgae blooms (red tides) in the Galician Rías, especially of the genus Dynophysis, has become a serious problem for the management and exploitation of industrial mussel farming. INTECMAR ${ }^{6}$ has been studying the relationship between farm closures in relation to toxicity episodes (Álvarez-Salgado et al. 2008 y 2011). These studies have made it possible to establish predictive variables in the contribution of continental waters and in the intensity of northerly winds. The results obtained have enabled to establish that the time for water renewal in the Rías Baixas is the key environmental variable that best explains why there are closures of mussel farms. The significant differences observed in the number of days/year that mussel farms

6 Technological Institute for the Monitoring of the Marine Environment in Galicia 
remain closed for public health reasons in the four Rías Baixas may be explained using a simple geomorphological index. Closures due to toxic phytoplankton in the Ría de Ares-Betanzos also depend to a great extent on weather conditions, although this dependence is not the same as in the Rías Baixas and differs in summer and autumn. Thus, a rainy spring will produce major closures due to lipophilic toxins in summer, and a summer with intense north-eastern winds will lead to major closures in autumn. All these studies were accompanied by the continued development of a 20-year database: "Mussel Lab Mar de Lorbé", recorded in collaboration with the PROINSA business group. This database has allowed to develop and to validate these bioecological (Fernandez-Reiriz et al. 2007, Duarte et al. 2008, 2010, and 2012) and bioeconomic (Fuentes-Santos et al. 2017) models and integrate them into the development of a Decision Support System (DSS) for the mussel industry.

\section{Conclusions}

With the consolidation and expansion of markets, and the growing competition from other countries in production and markets, it is worth asking whether the strategy of limiting the areas of production adopted forty years ago must be maintained. Probably the future of the Galician mussel industry will depend on the capacity to increase production and limit the impact of red tides on the exploitation cycles, and continue diversifying the types of products for the new demands of the consumer.

Special attention should be directed to the carrying capacity of ecosystems and their effects on crop yields, as well as to the possible incidences that variations related to climate change may produce. It will also be necessary to continue deepening the development of scientific and bioeconomic models that allow the implementation of a Decision Support System (DSS) that will increase knowledge in relation to the resilience of the ecosystem and not only its shortterm productivity.

\section{Acknowledgments}

Thanks to Dra. I. Fuentes-Santos for his continued collaboration in the prospection and evaluation of data. This study has been funded by the CSIC-PIE project (CSIC 201540E107).

\section{References}

Aguiar, E., Fuentes-Santos, I., Labarta, U., Alvarez-Salgado, X. A. , FernándezReiriz, M.J., 2015. Empirical modelling of seston quality based on environmental factors in a mussel culture area (NW Iberian upwelling system). Mar. Ecol. Prog. Ser. 536: 89-105. doi:10.3354/meps11368.

Aguiar, E., Piedracoba, S., Alvarez-Salgado, X. A. , Labarta, U., 2017. Circulation of water through a mussel raft: clearance area vs. idealized linear flows. Reviews in Aquaculture 9:3-22 doi:10.1111/ raq.12099. 
Aguirre, P., 1979. Biología de mejillón de cultivo en la Ría de Vigo. Bol. Inst. Esp. Ocean. $n^{\circ}$ 279: 75-126

Álvarez-Salgado, X.A., Labarta, U. , Fernández-Reiriz, M.J. , Figueiras, F.G. , Rosón, G. , Piedracoba, S. , Filgueira, R. , Cabanas, J.M. , 2008. Renewal time and the impact of harmful algal blooms on the extensive mussel raft culture of the Iberian coastal upwelling system. Harmful Algae 7: 849-855.

Álvarez-Salgado, X.A., Figueiras, F.G., Fernández-Reiriz, M.J., Labarta, U., Peteiro, L. Piedracoba, S., 2011.Control of lipophilic shellfish poisoning by seasonal upwelling and continental runoff. Harmfull Algae 10 : 121-129.

Álvarez-Salgado , X.A., Labarta, U. , Vinseiro, V., Fernández-Reiriz, M.J., 2017. Environmental drivers of mussels flesh yield in a coastal upwelling system. Ecological Indicators 77:323-329. dx.doi.org/10.1016/j.ecolind.2017.04.039.

Andreu B., 1976. El cultivo del mejillón en Europa. Anais de Acad. Brasileira Cinc., 47: 11-48.

Babarro, J.M.F., Fernández-Reiriz, M.J. , Labarta, U., 2000. Growth of seed mussel (Mytilus galloprovincialis): effects of the environmental parameters and seed origin J. Shellfish. Res. 19(1): 187-193.

Blanton, J.O., and others. 1987. The relationship of upwelling to mussel production in the Rías on the western coast of Spain. J. Mar. Res. 45: 497-511.

Campos, M.J., Fraga, S., Mariño, J., Sánchez, F.J.,1982. Red tide monitoring program in NW Spain. Report of 1977-1981. International Council for the Exploration of the Sea (ICES), Council Meeting L: 27.

Castelo, O. , y Perez-Dorca, A., 1997. El sector productor mejillonero: su crisis. Feuga. Consellería de Pesca. Santiago de Compostela.

Cranford, P.J., Duarte, P., Robinson, S.M.C. , Fernández-Reiriz, M. J. , Labarta, U., 2014. Suspended particulate matter depletion and flow modification inside mussel (Mytilus galloprovincialis) culture rafts in the Ría de Ares, Spain. J. Experimental Marine Biology and Ecology 452:70-81 http://dx.doi.org/10.1016/j.jembe.2013.12.005.

Cubillo, A.M., Peteiro, L.G., Fernández-Reiriz, M.J., Labarta, U., 2012. Influence of stocking density on growth of mussels Mytilus galloprovincialis in suspended culture. Aquaculture 342-343: 103-111.

Cubillo A.M., Fuentes-Santos, I., Labarta, U., 2015. Interaction between stocking density and settlement on population dynamics in suspended mussel culture . J. Sea Research 95:84-94 doi: 10.1016/j.seares.2014.09.009.

Duarte P., Labarta , U. , Fernández-Reiriz, M.J., 2008. Modelling local food depletion effects in mussel rafts of Galician Rias. Aquaculture 274: 300-312. 
Duarte,P, Fernández-Reiriz, M.J., Filgueira, R. , Labarta, U., 2010.Modelling mussel growth in ecosystems witn low suspended matter loads. J. Sea Res. 64: 273-286.

Duarte P., Fernandez-Reiriz, M. J. , Labarta, U., 2012.Modelling mussel growth in ecosystems with low suspended matter loads using a Dynamic Energy Budget approach. J. Sea Res. 67: 44-57.

Duarte P., Alvarez-Salgado, X.A. , Fernandez-Reiriz, M.J. , Piedracoba, S. , Labarta, U., 2014. A modelling study on the hydrodynamics of a coastal embayment occupied by mussel farms (ria de Ares-Betanzos, NW Iberian Peninsula). Estuarine, Coastal and Shelf Science 147: 42-55 http://dx.doi:10.1016/j.ecss.2014.05.021.

Durán, C., Acuña, R. , Santiago, J. , 1990. El mejillón, biología, cultivo y comercialización. Fundación Caixa Galicia. A Coruña

Escuela de Negocios Caixanova, 2000. La contribución de la actividad mejillonera al desarrollo local de Galicia. Mexillon de Galicia.Consello Regulador. Sipsa Graphics.Vigo.178 pp.

EUMOFA,2016. The EU fish market. 2015 Edition. www.eumofa.eu.

EUMOFA,2018. The EU fish market. 2017 Edition. www.eumofa.eu.

Fernández-González, A.I., 2005. De la roca a la cuerda. Orígenes y desarrollo de la industria mejillonera en Galicia (1946-2005). VIII Congreso de la Asociación Española de Historia Económica. Santiago de Compostela, 13-16 de septiembre de 2005

Fernández-González, A. I. , Giráldez J., 2013. Acuicultura y globalización:el caso de la industria del mejillón DT-AEHE N¹301. www.aehe.net.

Fernández-Reiriz, M.J. ,Labarta, U., 2004. Procesos fisiológicos y disponibilidad de alimento del mejillón en las rías gallegas. In U. Labarta (Cd). Bateeiros, mar, mejillón. Una perspectiva bioeconómica. CIEF. Fundación Caixagalicia. Santiago. pp 45-73.

Fernández-Reiriz, M.J., Duarte, P., Labarta, U., 2007. Modelos de comportamiento alimentario en el mejillón de las Rías de Galicia. In Biologia y Cultivo del mejillón (M. galloprovincialis) en Galicia .Madrid. CSIC. Biblioteca de Ciencias 26. pp. 195-223. ISBN: 978-84-00-08526-1.

Figueras Monfort, A., 1976.Desarrollo actual del cultivo del mejillón (Mytilus edulis L.) y posibilidades de expansión. FAO Technical Conference on Aquaculture. FIM: AQ/Conf./76/R.7, Kyoto, 20 pp. FAO, Rome, Italy.

Fuentes-Santos I., Labarta, U., 2015. Spatial patterns of larval settlement and early post-settlement survivorship of Mytilus galloprovincialis in a Galician Ría (NW
Con formato: Inglés (Estados Unidos)

Con formato: Inglés (Estados Unidos) 
Spain). Effect on recruitment success. Regional Studies in Marine Science 2: 110. doi10.1016/j.rsma.2015.08.006

Fuentes-Santos I., Cubillo, A.M., Fernández-Reiriz, M. J., Labarta, U. 2014. Dynamic self-thinning model for sessile animal population with multilayered distribution.

Reviews in Aquaculture. 6:115-127. http://dx.doi.org/10.1111/raq.12032.

Fuentes-Santos I., Cubillo, A.M. Labarta, , U. ,2017. A bioeconomic approach to optimize mussel culture production. Reviews in Aquaculture 9:125-140 doi:10.1111/raq 12108.

Fuentes-Santos I., Labarta, U. , Arranz, K. , Fernández-Reiriz, M.J. ,2017. From classical to nonparametric growth models: towards comprehensive modelling of mussel growth patterns. Mar. Env. Res. 127:41-48 doi 10.1016/j.marenvres.2017.03.004.

Fuentes-Santos I., Labarta, U. Álvarez-Salgado, X. A. , Fernández-Reiriz, M. J. , 2016. Solar irradiance dictates settlement timing and intensity of marine mussels. Scientific Reports 6:29405 | DOI: 10.1038/srep29405.

Gestal, J.J.,2003. Aspectos epidemiológicos de la intoxicación por toxina diarreica de los moluscos (DSP). Anal. Real Acad. Nal. Farm. 69: 169-201

Labarta, U., 1997. Marisqueo: cultura y economía del carbonato cálcico. World Fishing. La Voz de Galicia. 17 de Septiembre de 1997.

Labarta, U. ,2000. Desarrollo e innovación empresarial en la acuicultura: una perspectiva gallega en un contexto internacionalizado, CIEF, Fundación Caixagalicia, A Coruña.

Labarta, U., Corbacho, E. P., 2002. La industria del mejillón: mercados internacionales, productos y países, CIEF, Fundación Caixagalicia, A Coruña.

Labarta, U., 2004. El mejillón, un paradigma bioecónomico. In U. Labarta (Cd). Bateeiros, mar, mejillón. Una perspectiva bioeconómica. CIEF.Fundación Caixagalicia. Santiago. pp 15-43.

Mariño, J., Pérez-Camacho, A. , González, R., 1982. El cultivo de mejillón en la ría de Arousa. Boletín IEO 7(2): 297-308.

MacAlister and partners Ltd. (1999). Forward study of community aquaculture. European Commision. Directorate General Fisheries.

Monfort, M.C., 2014. The European Market for Mussels. Globefish Research Programme. Vol 115.Rome. FAO. 65 pp.

Perez-Camacho, A., Gonzalez , R. , Fuentes, J., 1991. Mussel culture in Galicia. Aquaculture 94: 263-278. 
Pérez-Camacho, A. , Labarta, U.,2004. Rendimientos y producción del mejillón: Bases biológicas para la innovación. In U. Labarta (Cd). Bateeiros, mar, mejillón. Una perspectiva bioeconómica. CIEF. Fundación Caixagalicia. Santiago.pp 93121.

Pérez-Camacho, A., Labarta, U. , Navarro, E. ,2000. The energy balance of mussels (Mytilus galloprovincialis Lmk): The effect of length and age. Mar. Ecol Prog. Ser. 199: 149-158.

Pérez-Camacho, A., Labarta, U. „Beiras, R.,1995. Growth of Mussel (Mytilus edulis galloprovincialis) in cultivation raft . Influence of seed source, cultivation site and food availability. Aquaculture 138:349-362.

Pérez-Camacho A., Labarta, U. , Vinseiro, V. , Fernandez-Reiriz, M.J.,2013. Mussel Production Management: Raft culture without thining-out. Aquaculture. 406-407:172-179 http://dx.doi.org/10.1016/j.aquaculture.2013.05.019.

Pérez-Camacho A., Aguiar, E. , Labarta, U. , Vinseiro, V. , Fernandez-Reiriz, M.J. ,. Alvarez-Salgado, X. A., 2014. Ecosystem-based indicators as a tool for mussel culture management strategies. Ecological Indicators 45: 538-548 doi: 10.1016/j.ecolind.2014.05.015.

Peteiro L. G., Filgueira, R. , Labarta, U., Fernández-Reiriz, M.J., 2010. The role of fish predation on recruitment of Mytilus galloprovincialis on different artificial mussel collectors. Aquacultural Engineering 42(1): 25-30.

Peteiro L. G., Labarta, U. , Fernández-Reiriz, M.J. , Álvarez-Salgado, X.A. , Filgueira, R. , Piedracoba, S.2011. Influence of intermittent-upwelling on Mytilus galloprovincialis settlement patterns in the Ria de Ares-Betanzos. Mar. Ecol Prog. Ser. 443:111-127.

Piedracoba, S., Álvarez-Salgado, X. A. , Labarta, U. , Fernández-Reiriz, M. J. , Gómez, B., Balseiro, C.,2014. Water flows through mussel rafts and their relationship with wind speed in a coastal embayment (Ría de Ares-Betanzos, NW $\begin{array}{llll}\text { Spain). } & \text { Continental } & \text { Shelf } & \text { Research. }\end{array}$ http://dx.doi.org/10.1016/j.csr.2013.12.007 .

Porta F., Pardellas J., 1987. El cultivo del mejillón en España, Cuadernos del FROM n ${ }^{\circ} 14$. MAPA. Madrid.

Schumpeter, J. A. (1942): Capitalism, Socialism and Democracy, Nueva York, Harper \& Brothers. Cited of the Spanish translation: Capitalismo, Socialismo y Democracia, 1984, Barcelona, Folio.

Somega, 1975. Estudio de la situación económica de los tres sectores del mejillón. Sodiga. Imprenta Moret. A Coruña. 270 pp.

Tenore, K.R., González, N. 1975. Food chain patterns in the Ría de Arousa, Spain: an area of intense mussel aquaculture. Paper presented at the 10th 
European Symposium of Marine Biology, Ostende, Belgium. Wetteren: IZWO/Universa Press: Wetteren.

Tenore, K.R., Boyer, L.F., Cal, R.M., Corral, J., et al., 1982. Coastal upwelling in the Rías Bajas, NW Spain: contrasting benthic regimes of the Rías de Arousa and the Muros. J. Mar. Res. 40: 701-722.

Wiegert, R.G., Penas-Lado, E, 1982. Optimal exploitation, by mussel 489 rafts, off the Ria de Arosa, Spain: predictions of a first-generation model. Paper presented at the Workshop on Marine Ecosystems modelling, Frederick, Maryland. Washington DC: US .Department of Commerce, NOAA, National Environmental Satellite Data, and Information Service.

\section{Captions of figures}

Fig.1. Mussel rafts between 1956 and 1976

Fig.2. Growth of production between 1956 and 2016

Fig.3. Distribution of rafts and the production in the Rias of Galicia

Fig.4. Distribution of rafts by owner in the Rias of Galicia

Fig.5. Spanish import and export of mussels by products classes (fresh, canned, frozen and non-hermetic conserves) in tons and thousands euros.

Fig.6. Production (tons) by market type (fresh and industry)

Fig.7. Evolution of the marketed tons of fresh mussel by qualities

Con formato: Español (alfab. internacional) 


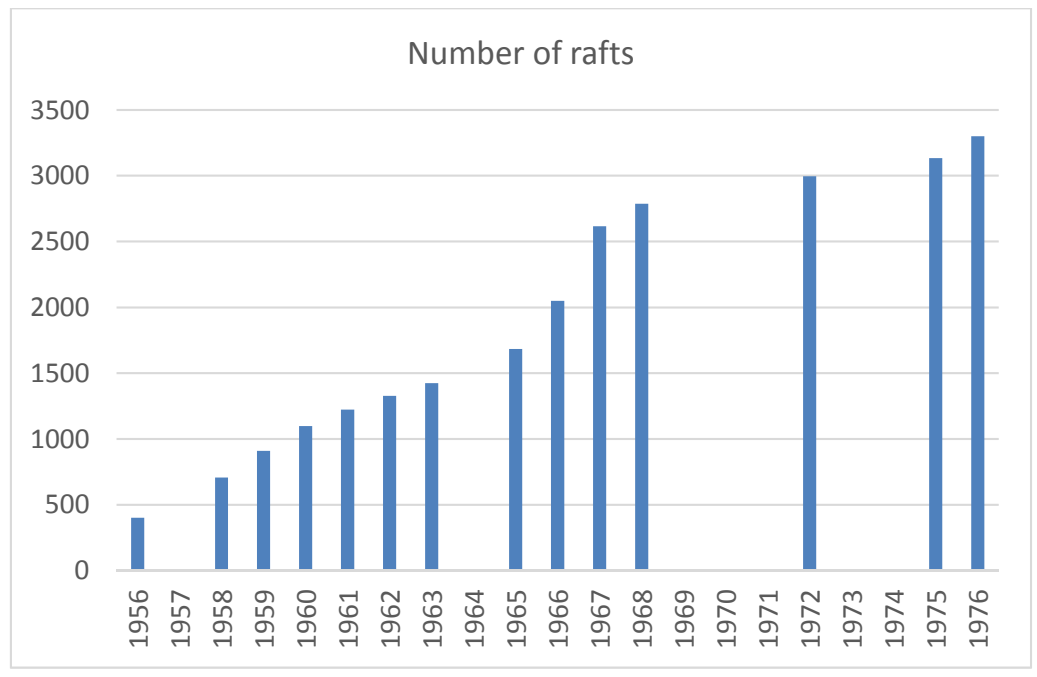

\section{Figure 1}

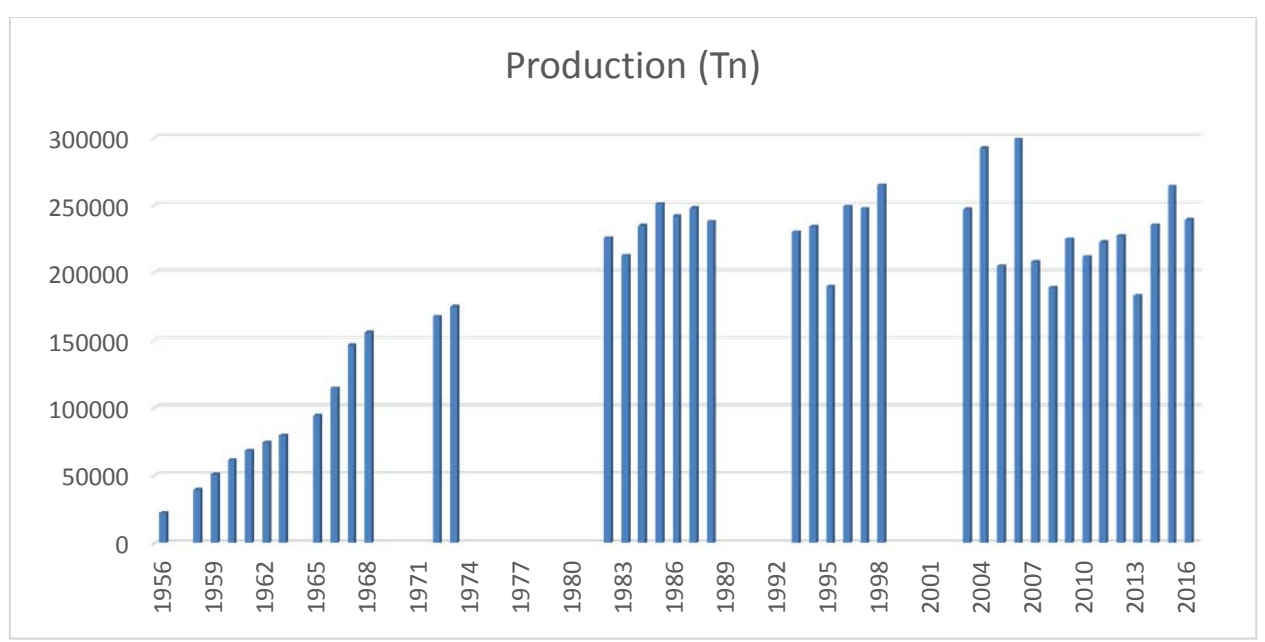




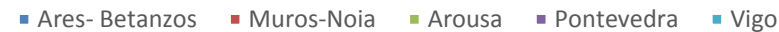

\section{Production $(T n)$}

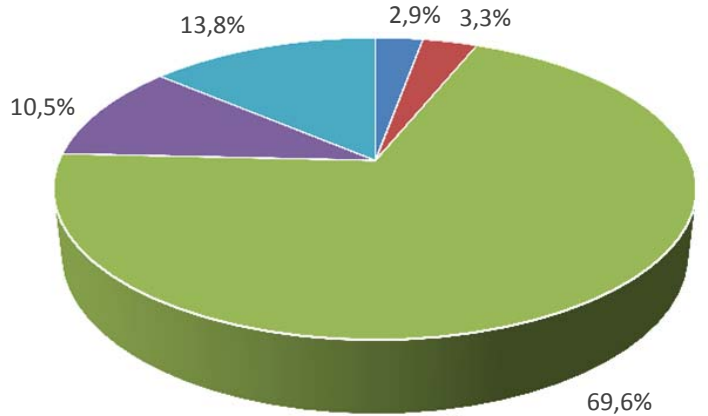

- Ares-Betanzos " Muros-Noia " Arousa "Pontevedra "Vigo

\section{Number of rafts}

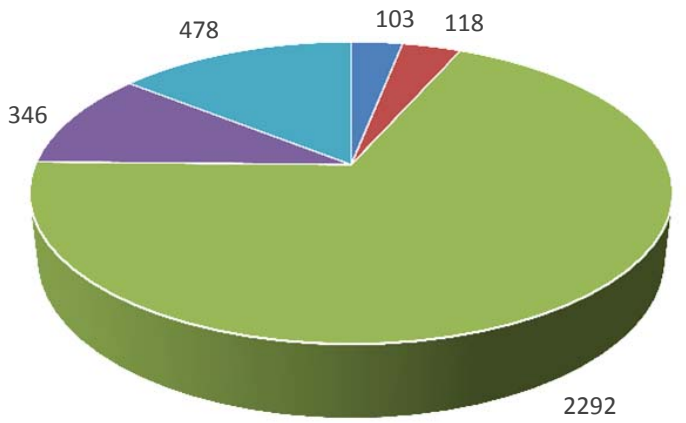

- Ares- Betanzos - Muros-Noia = Arousa - Pontevedra - Vigo 


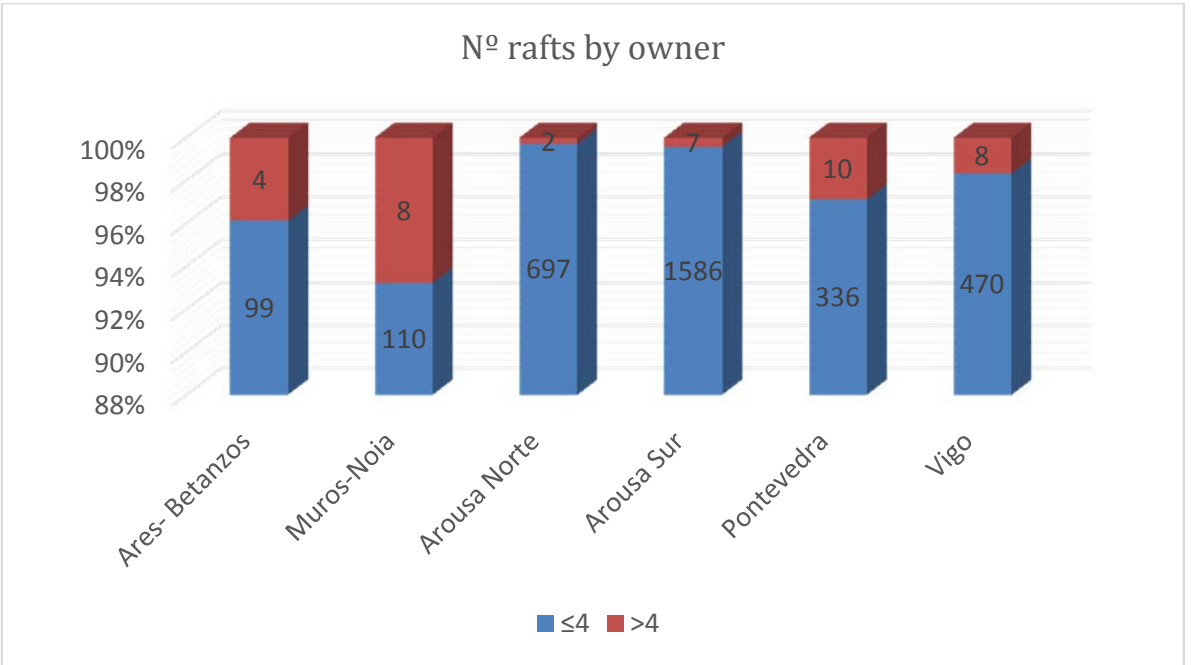



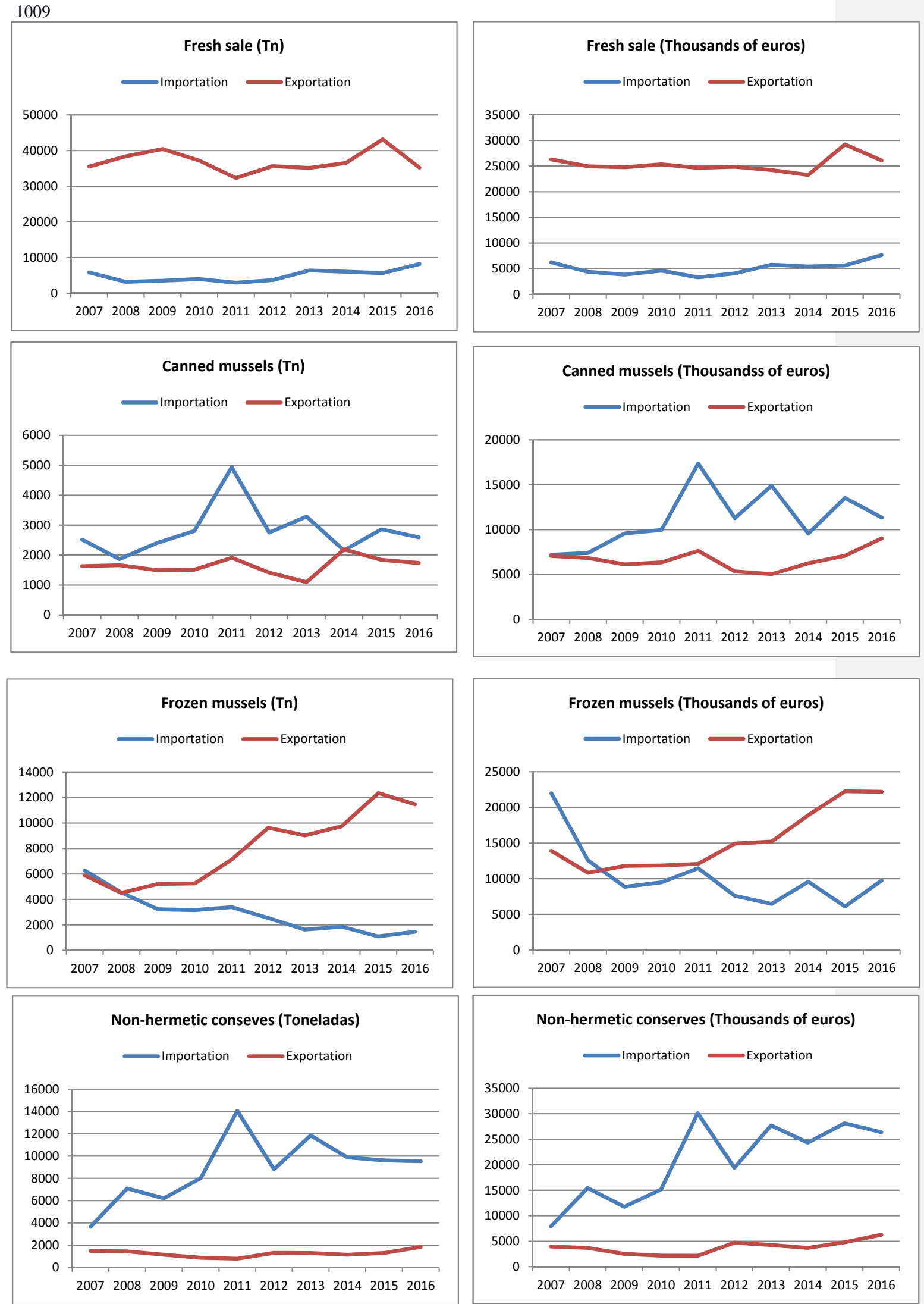


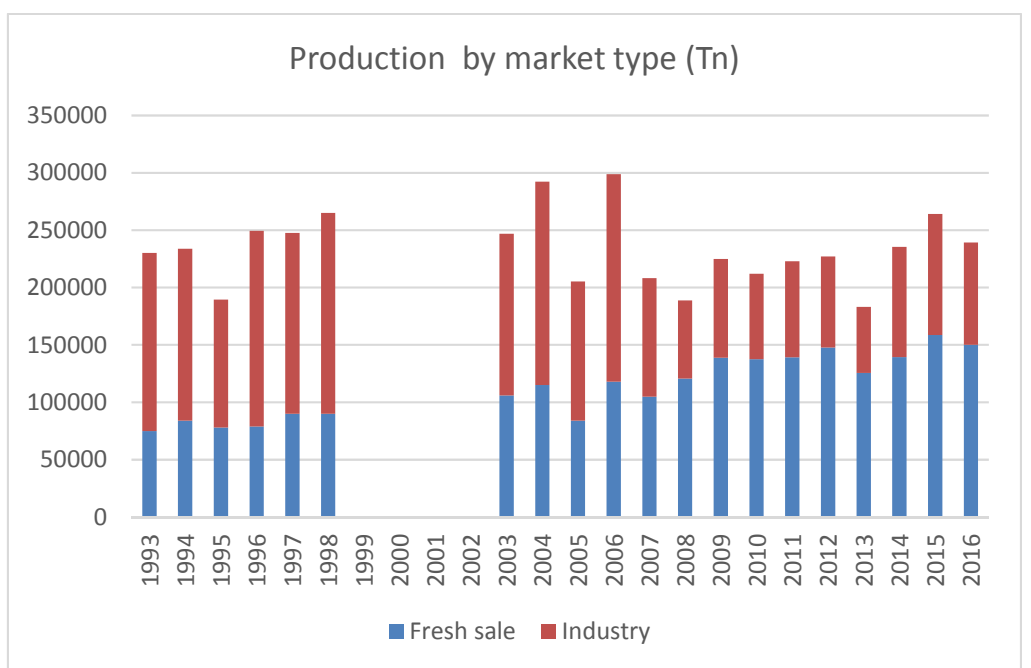

Figure 6 


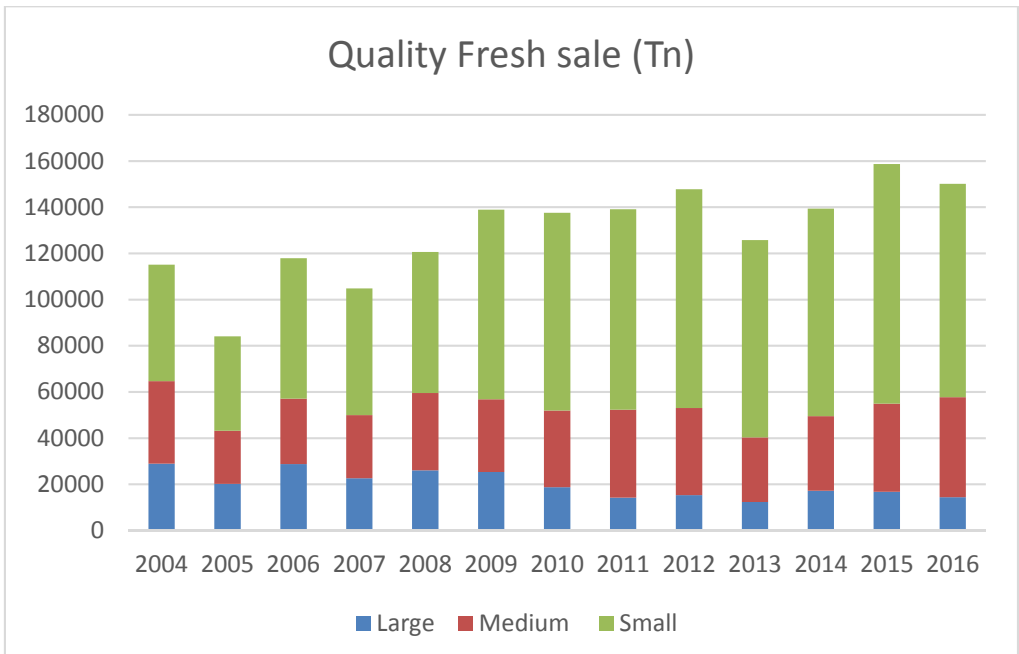

1022

1023 Figure 7

1024 